\title{
Sperm motility, fertilization, and larval development of silver catfish (Rhamdia quelen) in copper-contaminated water
}

\section{Motilidade espermática, fertilização e desenvolvimento inicial de jundiá (Rhamdia quelen) em água contaminada com cobre}

\author{
Robie Allan Bombardelli1 ${ }^{*}$; Giovano Neumann²; Cesar Pereira Rebechi de Toledo ${ }^{3}$; \\ Eduardo Antônio Sanches ${ }^{4}$; Denise Nascimento de Bastos ${ }^{3}$; \\ José Dílson Silva de Oliveira ${ }^{1}$
}

\begin{abstract}
The objective of this study was to evaluate the effect of copper-contaminated water on sperm motility, fertilization, and embryonic and larval development of silver catfish (Rhamdia quelen). A randomized experimental design with five treatments and four replicates was used. Two experiments were carried out: (1) controlled fertilization was performed under different levels of copper contamination and egg hatching was performed in clean water; and (2) copper-contaminated water was used for both fertilization and hatching assays. The time of sperm motility and sperm motility rates linearly decreased with increasing copper concentration in the water. Fertilization and hatching rates were also affected when the concentrations of copper in the water were above $0.0979 \mathrm{mg} \mathrm{Cu}^{+2} \mathrm{~L}^{-1}$ and $0.0331 \mathrm{mg} \mathrm{Cu}^{+2} \mathrm{~L}^{-1}$, respectively. Gamete exposure to levels between $15 \mathrm{mg} \mathrm{Cu}^{+2} \mathrm{~L}^{-1}$ and $60 \mathrm{mg} \mathrm{Cu}^{+2} \mathrm{~L}^{-1}$ for short periods of time negatively affected sperm motility, oocyte fertilization, and egg hatching rates. In addition, when gametes and embryos were exposed at levels above $0.03 \mathrm{mg} \mathrm{Cu}^{+2} \mathrm{~L}^{-1}$ during long periods of time, egg hatching rates were reduced, and at levels between $0.05 \mathrm{mg} \mathrm{Cu}^{+2} \mathrm{~L}^{-1}$ and $0.20 \mathrm{mg} \mathrm{Cu}^{+2} \mathrm{~L}^{-1}$ the number of abnormal larvae increased.
\end{abstract}

Key words: Embryo. Fish. Heavy metal. Reproduction. Spermatozoa.

\section{Resumo}

O objetivo deste estudo foi avaliar o efeito da água contaminada de cobre na motilidade espermática, fertilização e desenvolvimento embrionário e larval de jundiá (Rhamdia quelen). O delineamento experimental foi inteiramente casualizado, com cinco tratamentos e quatro repetições. Dois ensaios foram conduzidos: (1) a fertilização controlada foi realizada com diferentes níveis de água contaminada com cobre e a incubação do ovo realizada em água limpa; e (2) a contaminação da água foi utilizada tanto na fertilização e quanto na incubação dos ovos. O tempo de motilidade de espermatozóides e as taxas de motilidade do esperma foram reduzidas com o aumento da concentração de cobre na água. As taxas de fertilização e eclosão também foram afetados quando as concentrações de cobre na água

${ }^{1}$ Profs. Associados, Centro de Engenharia e Ciências Exatas, Universidade Estadual do Oeste do Paraná, UNIOESTE, Toledo, PR, Brasil. E-mail: rabombardelli@gmail.com; jdilson.sol@gmail.com

${ }^{2}$ Discente de Doutorado em Recursos Pesqueiros e Engenheira de Pesca, UNIOESTE, Toledo, PR, Brasil. E-mail: giovanoneumann@hotmail.com

3 Mestres Recursos Pesqueiros e Engenharia de Pesca, UNIOESTE, Toledo, PR, Brasil. E-mail: cprtoledo@gmail.com; denisenbastos@hotmail.com

${ }^{4}$ Prof. Dr., Departamento Aquicultura, Universidade Estadual Paulista Júlio de Mesquita Filho, UNESP, Registro, SP, Brasil. E-mail: eduanches@hotmail.com

* Author for correspondence 
estavam acima de $0,0979 \mathrm{mg} \mathrm{Cu}^{+2} \mathrm{~L}^{-1} \mathrm{e} 0,0331 \mathrm{mg} \mathrm{Cu}^{+2} \mathrm{~L}^{-1}$, respectivamente. A exposição dos gametas

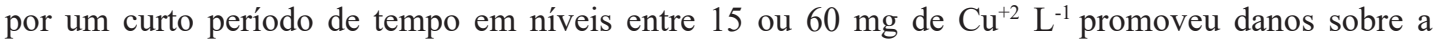
motilidade dos espermatozóides, a fertilização de oócitos e a eclosão dos ovos. Além disso, quando os gametas e embriões foram expostos a níveis acima de $0,03 \mathrm{mg} \mathrm{de} \mathrm{Cu}^{+2} \mathrm{~L}^{-1}$ por um longo período de tempo, a eclosão dos ovos foi reduzida, e em níveis de 0,05 a $0.20 \mathrm{mg} \mathrm{Cu}^{+2} \mathrm{~L}^{-1} \mathrm{o}$ anormalidade larval aumentou.

Palavras-chave: Embrião. Espermatozóides. Metais pesados. Peixe. Reprodução.

\section{Introduction}

Reports on the lethal effect of contaminated water on aquatic organisms resulting from human activities such as the release of pesticides and heavy metals, have aroused concern (SCOTT; SLOMAN, 2004). Even sublethal concentrations may have medium- and long-term consequences such as reduced reproduction in fish. In the water, gametes are exposed to pollutants (ABASCAL et al., 2007) that can modify their features (DIETRICH et al., 2012), reducing or preventing natural or artificial propagation (WITECK et al., 2011).

There have been several reports on the influence of heavy metals on the quality of gametes (LAHNSTEINER et al., 2004), fertilization of oocytes (RURANGWA et al., 1998), sperm motility, egg hatching (WITECK et al., 2011), and quality of larvae (SARNOWSKI, 2004). Among several pollutants, copper is a potential pollutant of water bodies because it derives from agricultural, industrial, and domestic effluents (MILESI et al., 2008). Considering the complex interactions between pollutants and aquatic biological systems, it is important to continue studying the effects of heavy metals on the reproductive processes of freshwater fish and their potential impact on natural populations and aquaculture production.

The present study was carried out to evaluate the effect of copper-contaminated water on sperm motility, controlled fertilization, and embryonic and larval development of the silver catfish (Rhamdia quelen). $R$. quelen is an important species to fisheries and aquaculture in South America, and is widely used as a biological model in reproductive research (KOAKOSKI et al., 2012).

\section{Materials and Methods}

Two experiments were carried out to evaluate the effects of copper-contaminated water on sperm and oocytes during fertilization and on egg incubation. In the first, oocyte fertilization and egg incubation were performed in uncontaminated water, whereas in the second, copper-contaminated water was used.

Males and females of silver catfish (Rhamdia quelen) were kept in a $200 \mathrm{~m}^{2}$ earthen pond with water supply to compensate for water loss through evaporation and infiltration. Fish were fed commercial feed containing $32 \%$ crude protein.

Experiment 1: Gametes exposure and fertilization of oocyte in copper-contaminated water and egg incubation in uncontaminated water

Seven females $(263.00 \pm 74.37 \mathrm{~g})$ and five males $(173.60 \pm 22.30 \mathrm{~g})$ were used in the experiment. Selected females exhibited a rounded abdomen, reddish urogenital papilla, and uniform oocyte color and size (SANCHES et al., 2011a). Males releasing sperm after gentle pressure on the abdomen were selected (SANCHES et al., 2011a).

The selected breeders were individually weighed, marked, and separated according to sex in two tanks equipped with aeration and constant water renewal. Hormonal induction to synchronize ovulation or spermiation was performed by injecting carp pituitary extract (CPE) intramuscularly into the dorsal region (BOMBARDELLI et al., 2006). In females, hormonal manipulation was applied in two doses. The first one comprised $0.5 \mathrm{mg}$ CPE. $\mathrm{kg}^{-1}$ and the second, applied 12 hours later, had a 
concentration of $5.0 \mathrm{mg} \mathrm{CPE} . \mathrm{kg}^{-1}$ (SANCHES et al., 2011a). Males underwent hormonal manipulation with a single dose of $3 \mathrm{mg} \mathrm{CPE} . \mathrm{kg}^{-1}$.

Water physico-chemical parameters were monitored every 2 hours. Dissolved oxygen (Hanna digital oximeter F-HI 9147), pH (Hanna digital pH meter F-HI 8424), and electrical conductivity (Hanna, HI 99301) were $4.25 \pm 0.077 \mathrm{mg} \mathrm{L}^{-1}$,

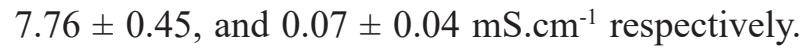
Temperature was maintained at $27.35 \pm 1.91^{\circ} \mathrm{C}$.

Gametes were collected at 240 accumulated thermal units after the last hormonal application (corresponding to $8 \mathrm{~h}$ and $46 \mathrm{~min}$ at a water temperature of $27.35{ }^{\circ} \mathrm{C}$ ). Individual fish were caught, dried with a paper towel, and subjected to abdominal massage in the cephalocaudal direction (WITECK et al., 2011). The first batches of oocytes and drops of sperm were discarded in order to avoid possible contamination with urine or feces (BROOKS et al., 1997). Remaining oocytes were collected in a Petri dish (ambient temperature of 25 ${ }^{\circ} \mathrm{C}$ ). Approximately $5 \mathrm{~mL}$ of sperm was collected in a test tube $(\sim 0.1 \mathrm{~mL})$ (ambient temperature of 25 $\left.{ }^{\circ} \mathrm{C}\right)$. Sperm was stored at $12{ }^{\circ} \mathrm{C}$ during the period of time required to conduct manipulation experiments (TESSARO et al., 2012). Oocytes and sperm from each breeder were separately mixed and stored, according to Sanches et al. (2011a).

Sperm parameters were assessed by measuring time of sperm motility (ROMAGOSA et al., 2010), sperm survival rate (TESSARO et al., 2012), and sperm concentration (SANCHES et al., 2011b). Time of sperm motility and fertilization assays were performed using a randomized experimental design comprising five treatments with four replicates each. Based on pilot experiments, different levels of copper-contaminated water $(0.0,15.0,30.0$, 45.0 , and $\left.60.0 \mathrm{mg} \mathrm{Cu}^{+2} \mathrm{~L}^{-1}\right)$ were considered. Contaminated water samples were used for gamete activation and to conduct controlled fertilization. Eggs were incubated in uncontaminated water. The experimental units (in duplicate) for fertilization assays consisted of 2.5-L incubators with a water recirculation system, containing 2,387 \pm 45 eggs. Incubators were kept under controlled temperature $\left(25 \pm 1^{\circ} \mathrm{C}\right)$. For sperm motility assays, a sample from the sperm pool was diluted in copper-contaminated water.

Pilot experiments used the same experimental set up and protocols but a smaller number of incubators and water volume. In these assays, different concentrations of copper were added to the water to determine embryonic mortality. These results were used to choose the lowest copper concentration and plan the experimental treatments. Pilot assays were repeated as many times as necessary until the lethal concentration could be determined.

For the controlled fertilization assays, 100 $\mu \mathrm{L}$ of sperm (BOMBARDELLI et al., 2006) was added to $2 \mathrm{~mL}$ of oocytes $(2,387 \pm 45$ oocytes $)$. Gametes were activated by adding $20 \mathrm{~mL}$ of copper-contaminated water, using Copper II Nitrate Trihydrate P.A. (Vetec Chemicals ${ }^{\circledR}$ ). Immediately after water contamination, gametes and water were kept in gentle motion for 60 seconds. Subsequently, eggs were washed three times and incubated in uncontaminated water.

Electrical conductivity, $\mathrm{pH}$, and dissolved oxygen of the water where eggs were incubated were measured before fertilization (time $=0$ hours) and eight hours later (time $=8$ hours). Fertilization rates were determined eight hours after activation of gametes (HILBIG et al., 2008) by counting three samples of $183 \pm 45$ eggs from each experimental unit. Twenty-four hours after gamete activation (when most eggs had hatched), 100 larvae from each experimental unit were collected and reared for 21 days in uncontaminated water to determine survival rates. The remaining larvae in the incubators were fixed in $4 \%$ buffered formalin solution and counted to estimate egg hatching rates. Fixed larvae were observed under a stereomicroscope $(\times 10)$ in order to determine the percentage of normal larvae (SANCHES et 
al., 2011a). Larval development was classified as normal or abnormal according to Jezierska et al. (2000).

Larvae used in the rearing experiments were kept in incubators for 4 days to develop their swimming abilities. They were then transferred to 20 PVC aquaria of $30 \mathrm{~L}$ each, at a density of 3.33 larvae $\mathrm{L}^{-1}$. Aquaria with a recirculation system and a total volume of $1.5 \mathrm{~m}^{3}$, were kept under controlled temperature conditions $\left(25.0 \pm 0.1{ }^{\circ} \mathrm{C}\right)$. Electrical conductivity, $\mathrm{pH}$, and dissolved oxygen were measured weekly.

Experiment 2: Gametes exposure, fertilization of oocyte and egg incubation in copper-contaminated water

Eight females $(255.0 \pm 57.32 \mathrm{~g})$ and six males $(216.7 \pm 58.54 \mathrm{~g})$ were selected to produce oocytes and sperm, as described previously. Controlled fertilization and incubation protocols, as well as the experimental set up were carried out as in experiment 1. Based on pilot assays (as described above), treatments consisted in using different concentrations of copper-contaminated water $\left(0.00,0.05,0.10,0.15\right.$, and $\left.0.20 \mathrm{mg} \mathrm{Cu}^{+2} \mathrm{~L}^{-1}\right)$. Each treatment was performed in a separate recirculation system and the copper-contaminated water from each treatment was used for controlled fertilization and incubation assays. The experimental units of the fertilization assays contained 2,660 \pm 20 eggs and fertilization rates were measured by counting three samples of $212 \pm 28$ eggs from each experimental unit. Gametes and embryos were kept in coppercontaminated water until egg hatching.

The analysis of sperm parameters was done as described before, except concerning the determination of sperm motility. Motility was assessed by subjective estimation under a light microscope $(\times 400$; adapted from VIVEIROS et al., 2012; HERNANDEZ CUADRADO et al., 2014). For this, $80 \mu \mathrm{L}$ of sperm was diluted in $800 \mu \mathrm{L}$ of copper-contaminated water.
Fertilization and egg hatching rates, larval development, and larvae survival after 21 days of rearing were determined as described in experiment 1 . Water physico-chemical parameters in the incubation assays were measured just before fertilization (time $=0$ hours) and eight hours later (time $=8$ hours), at the beginning of egg hatching, and at the end of egg hatching.

\section{Statistics analysis}

One-way analysis of variance (ANOVA) and linear regression analysis (5\% significance level) were used to analyze the results. The assumptions of normality and homogeneity of variances were checked. Statistical analysis was performed using STATISTICA $7.0^{\circledR}$.

\section{Results}

Electrical conductivity, dissolved oxygen, $\mathrm{pH}$, and temperature of the water used in egg incubation assays remained stable in both experiments (Table 1 and Table 2). Females produced 1,990 \pm 20 oocytes $\mathrm{mL}^{-1}$ and $1,330 \pm 10$ oocytes. $\mathrm{mL}^{-1}$, whereas males produced $7.57 \times 10^{10}$ sperm cells. $\mathrm{mL}^{-1}$ and 4.88 $\times 10^{10}$ sperm cells. $\mathrm{mL}^{-1}$, in the first and second experiments, respectively. Sperm survival rates were $92.6 \%$ and $93.5 \%$, and sperm motility was $29.33 \pm 1.91$ seconds and $22.30 \pm 1.02$ seconds, in the first and second experiments, respectively.

Table 1. Physicochemical parameters of the water used in the incubation systems to first experiment. Time zero $(0)$ hour corresponds to the moment of fertilization, and time eight (8) hours corresponds to eight hours after the fertilization ( $\mathrm{n}=4$ experimental unit).

\begin{tabular}{lcc}
\hline \multicolumn{1}{c}{ Parameters } & Time 0 hour & Time 8 hours \\
\hline $\begin{array}{l}\text { Electrical Conductivity } \\
\left(\mathrm{mS} \mathrm{cm}^{-1}\right)\end{array}$ & $0.08 \pm 0.01$ & $0.09 \pm 0.00$ \\
$\begin{array}{l}\text { Dissolved oxygen } \\
\left(\mathrm{mg} \mathrm{L}^{-1}\right)\end{array}$ & $4.50 \pm 0.34$ & $5.10 \pm 0.56$ \\
$\mathrm{pH}$ & $7.55 \pm 0.10$ & $7.73 \pm 0.09$ \\
Temperature $\left({ }^{\circ} \mathrm{C}\right)$ & $24.70 \pm 0.20$ & $25.00 \pm 0.30$ \\
\hline
\end{tabular}


Table 2. Physicochemical parameters of the water used in the egg incubation systems to second experiment. Time zero (0) hour corresponds to the moment of fertilization, time eight (8) hours corresponds to eight hours after the fertilization. Beginning and end of hatching correspond to the moment of beginning and end of egg hatching $(n=4$ experimental unit).

\begin{tabular}{lcccc}
\hline \multicolumn{1}{c}{ Parameter } & 0 hours & 8 hours & Beginning hatching & End hatching \\
\hline Electrical Conductivity $\left(\mathrm{mS} \mathrm{cm}^{-1}\right)$ & $0.04 \pm 0.00$ & $0.04 \pm 0.00$ & $0.04 \pm 0.00$ & $0.04 \pm 0.00$ \\
Dissolved oxygen $\left(\mathrm{mg} \mathrm{L}^{-1}\right)$ & $5.64 \pm 0.55$ & $5.15 \pm 1.01$ & $4.94 \pm 0.54$ & $5.70 \pm 0.73$ \\
$\mathrm{pH}$ & $7.92 \pm 0.08$ & $7.85 \pm 0.91$ & $8.23 \pm 0.10$ & $8.17 \pm 0.09$ \\
Temperature $\left({ }^{\circ} \mathrm{C}\right)$ & $24.20 \pm 0.17$ & $25.42 \pm 0.16$ & $25.12 \pm 0.11$ & $26.28 \pm 0.24$ \\
\hline
\end{tabular}

Experiment 1: Sperm parameters, fertilization and hatching rates, and larval normality and survival

The time of sperm motility was inversely proportional to the increase of copper concentration in the water $(\mathrm{p}<0.05)$. Motility was drastically compromised at concentrations of $45 \mathrm{mg} \mathrm{Cu} \mathrm{Cu}^{+2}$ $\mathrm{L}^{-1}$ and $60 \mathrm{mg} \mathrm{Cu}^{+2} \mathrm{~L}^{-1}$ (Figure 1) due to sperm agglutination. Agglutination indexes were not quantified.

Figure 1. Time of spermatozoa motility in semen of jundiá (Rhamdia quelen) diluted in water containing different concentrations of copper. Open circles represent valid data submitted to statistical analysis (The mean from an experimental unit resulted by the evaluation of three repetition; $n=4$ experimental unit). Full circles represents non valid data due occurrence of null results on all evaluations. The evaluations were carried out at $24.70 \pm 0.20{ }^{\circ} \mathrm{C}(\mathrm{n}=4)$.

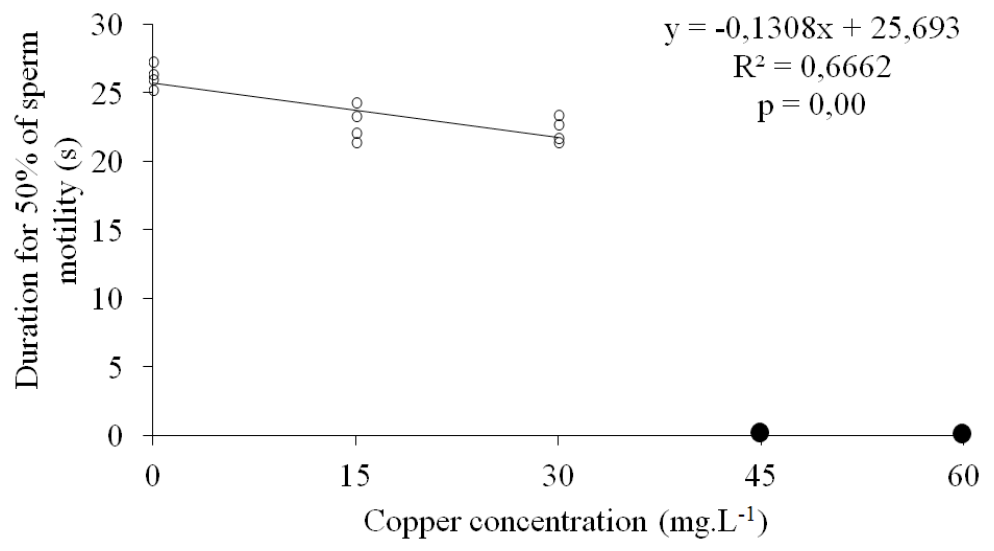

Fertilization and egg hatching rates also linearly decreased as water copper concentration increased $(\mathrm{p}<0.05)$ (Figure 2).

Copper-contaminated water did not influence larval development ( $\mathrm{p}>0.05$ ): $87.8 \pm 1.3 \%$ to $90.5 \pm 1.1 \%$ of the larvae were normal (Table 3 ).
Larval development was not analyzed at $60 \mathrm{mg}$ $\mathrm{Cu}^{+2} \mathrm{~L}^{-1}$ due to the reduced number of hatched eggs in this treatment. Similarly, copper-contaminated water did not affect survival rates of larvae reared for 21 days in uncontaminated water $(p>0.05)$ (Table 3). 
Figure 2. A) Controlled fertilization rates of oocytes, The fertilization mean from an experimental unit resulted by the evaluation of $183 \pm 45$ eggs; $n=4$ experimental unit; and B) Eggs hatch rates of silver catfish (Rhamdia quelen) submitted to gamete activation in copper-contaminated water and controlled incubation in uncontaminated water. The hatching mean from an experimental unit resulted by the evaluation of 2,387 \pm 45 eggs; $n=4$ experimental unit. The evaluations were carried out at $25.00 \pm 0.30{ }^{\circ} \mathrm{C}(\mathrm{n}=4)$.
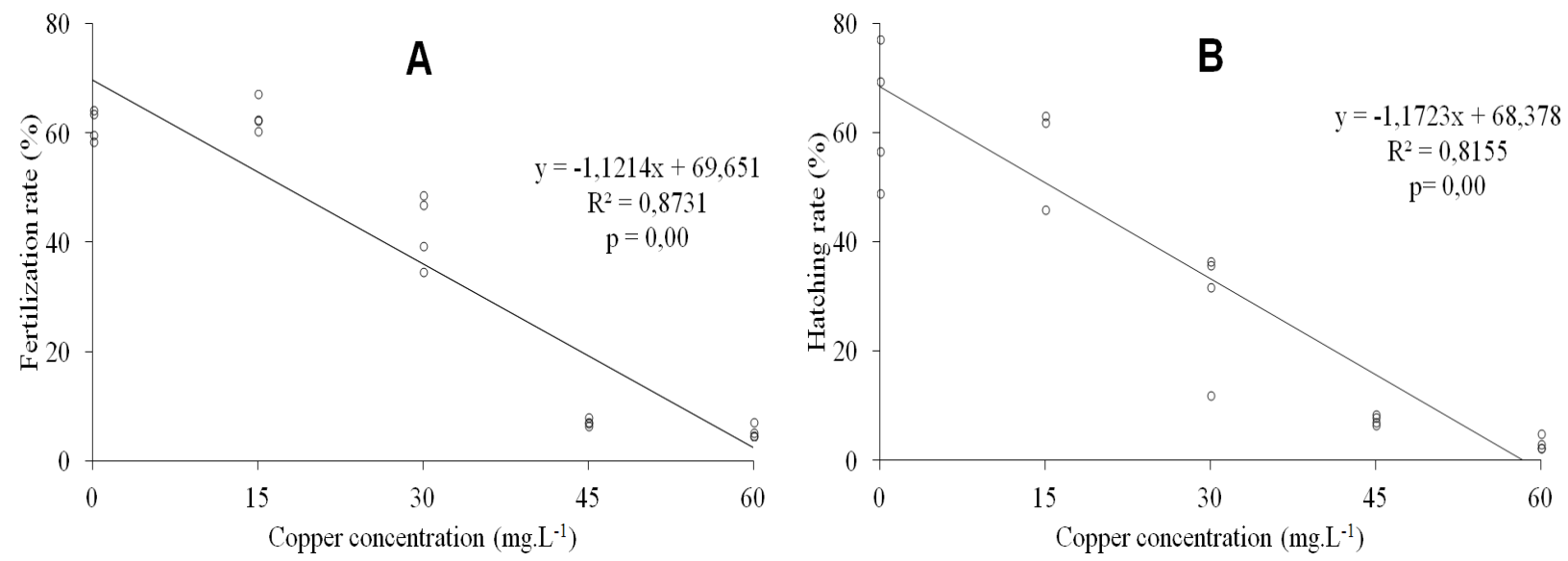

Table 3. Percentage of normal larvae immediately after egg hatching and percentage of survival of the progenies reared for 21 days in uncontaminated water. Progenies of silver catfish (Rhamdia quelen) derived from oocytes fertilized in water contaminated with different concentrations of copper, and eggs incubated in uncontaminated water.

\begin{tabular}{lcccccc}
\hline \multirow{2}{*}{\multicolumn{1}{c}{ Parameters }} & \multicolumn{6}{c}{ Concentration of copper in water $\left(\mathrm{mg} \mathrm{L}^{-1}\right)$} \\
\cline { 2 - 6 } & 0 & 15 & 30 & 45 & 60 & $\mathrm{p}$ \\
\hline Normal larvae (\%) & $89.3 \pm 2.7$ & $90.5 \pm 1.1$ & $90.0 \pm 1.6$ & $87.8 \pm 1.3$ & --- & 0.21 \\
Survival $(\%)^{2}$ & $32.5 \pm 32.0$ & $18.3 \pm 16.0$ & $25.0 \pm 12.9$ & $13.3 \pm 14.1$ & $15.3 \pm 5.5$ & 0.58 \\
\hline
\end{tabular}

${ }^{1}$ (The mean resulted by evaluation of 300 larvae, from an experimental unit; $n=4$ experimental unit). ${ }^{2}$ (The mean resulted by evaluation of 100 larvae, from an experimental unit; $\mathrm{n}=4$ experimental unit).

Experiment 2: Sperm parameters, fertilization and hatching rate, larval normality and survival

Results showed that even at low copper concentrations, the use of contaminated water during gamete activation caused damage to sperm motility. The time of sperm motility and sperm motility was inversely proportional to the increase in water copper concentration $(\mathrm{p}<0.05)$ (Figure 3).
After exposure of gametes and embryos to copper-contaminated water, fertilization and egg hatching rates exhibited a linear response plateau $(p<0.05)$. Model results suggest that problems related to fertilization and hatching may occur already at contamination levels of $0.0979 \mathrm{mg} \mathrm{Cu}^{+2}$ $\mathrm{L}^{-1}$ and $0.0331 \mathrm{mg} \mathrm{Cu}^{+2} \mathrm{~L}^{-1}$, respectively (Figure 4). At these contamination levels, estimated fertilization and hatching rates were $53.78 \%$ and $41.29 \%$ of the total amount of the oocytes and eggs, respectively (Figure 4). 
Figure 3. A) Time of spermatozoa motility, and B) Sperm motility rate in silver catfish (Rhamdia quelen) sperm diluted in water containing different levels of copper. The mean from an experimental unit resulted by the evaluation of three repetition; $n=4$ experimental unit. The evaluations were carried out at $24.20 \pm 0.17^{\circ} \mathrm{C}(\mathrm{n}=4)$.
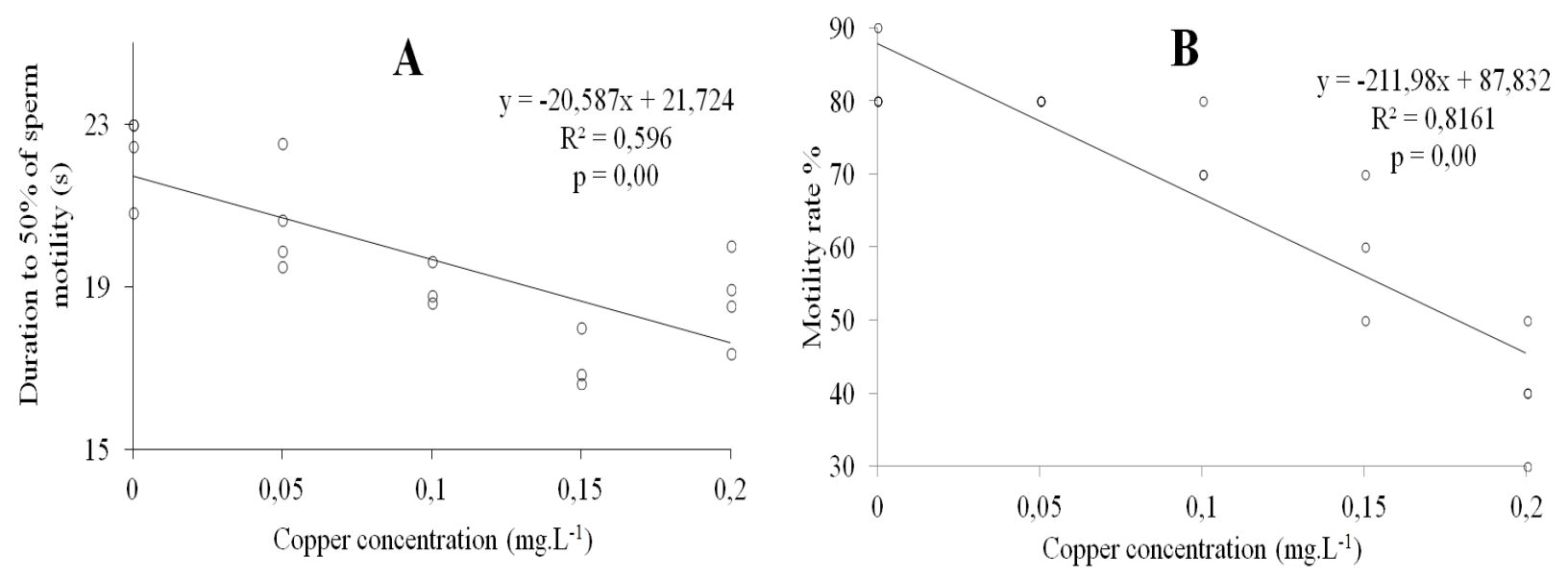

Figure 4. A) Controlled fertilization rates of oocytes, and B) Eggs hatch rates of silver catfish (Rhamdia quelen) submitted to gamete activation and controlled incubation of the eggs in water contaminated with different levels of copper. The fertilization mean from an experimental unit resulted by the evaluation of $212 \pm 28$ eggs; $n=4$ experimental unit. The hatching mean from an experimental unit resulted by the evaluation of $2,660 \pm 20$ eggs; $n=4$ experimental unit. The evaluations of fertilization and hatching rates were carried out at $25.42 \pm 0.16^{\circ} \mathrm{C}(\mathrm{n}=4)$ and $26.28 \pm 0.24^{\circ} \mathrm{C}$ $(n=4)$, respectively.

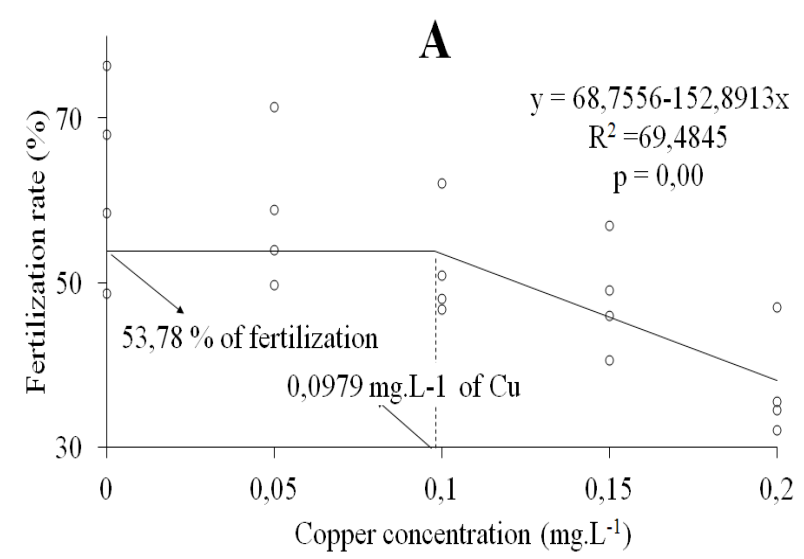

By maintaining gametes and embryos in contaminated water until hatching, the percentage of normal larvae decreased with an increase in the water copper concentration $(\mathrm{p}<0.05)$ (Figure 5).

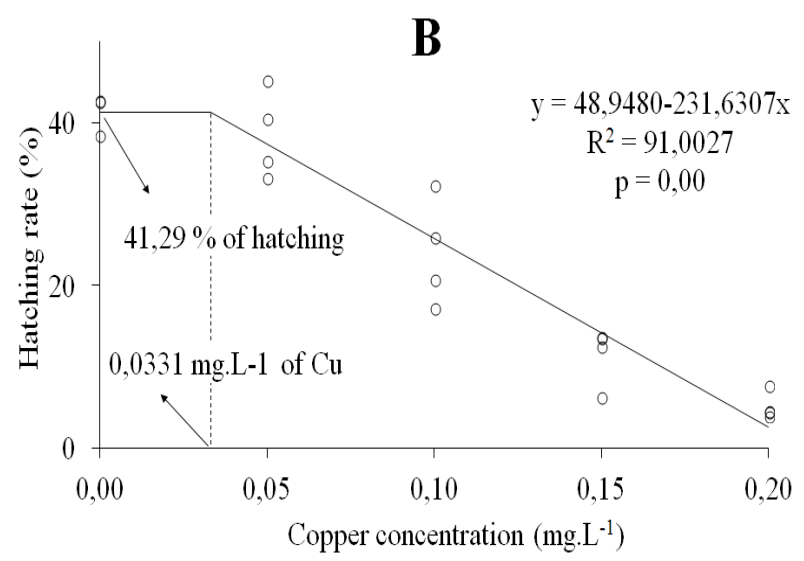

However, when gametes and embryos were reared for 21 days in uncontaminated water, no difference in survival rates was observed between treatments (Table 4). 
Figure 5. Percentage of normal larvae derived from silver catfish (Rhamdia quelen) progenies exposed to water containing different concentrations of copper from fertilization until the moment of egg hatching. The mean resulted by evaluation of 300 larvae, from an experimental unit; $n=4$ experimental unit.

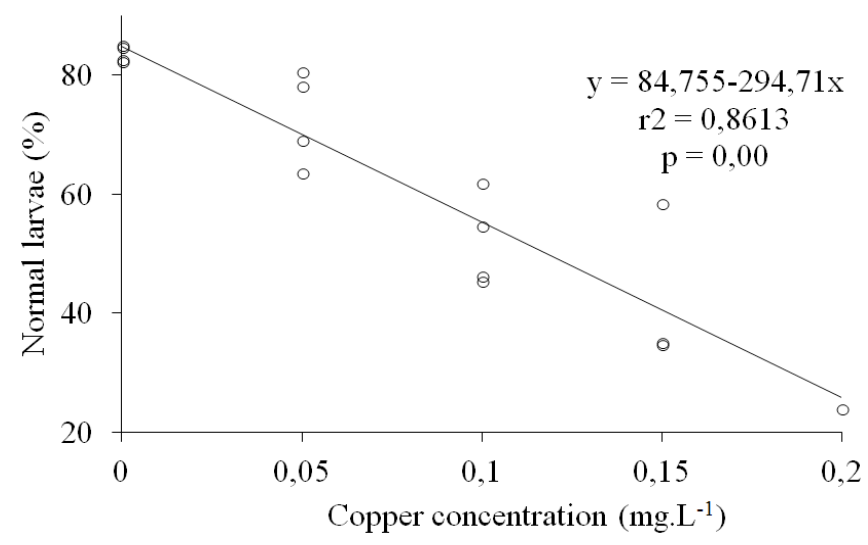

Table 4. Percentage of survival of the progenies reared for 21 days in uncontaminated water. Progenies of silver catfish (Rhamdia quelen) derived from fertilized oocytes and eggs incubated in water contaminated with different concentrations of copper.

\begin{tabular}{ccccccc}
\hline \multirow{2}{*}{ Parameter } & \multicolumn{5}{c}{ Concentration of copper in water $\left(\mathrm{mg} \mathrm{L}^{-1}\right)$} \\
\cline { 2 - 6 } & 0.00 & 0.05 & 0.10 & 0.15 & 0.20 & $\mathrm{p}$ \\
\hline Survival $(\%)^{1}$ & $55.5 \pm 28.5$ & $47.5 \pm 19.0$ & $71.5 \pm 6.6$ & $69.5 \pm 10.7$ & $68.5 \pm 6.9$ & 0.23 \\
\hline
\end{tabular}

${ }^{1}$ (The mean resulted by evaluation of 100 larvae, from an experimental unit; $n=4$ experimental unit).

\section{Discussion}

During both experiments, water electrical conductivity, dissolved oxygen, $\mathrm{pH}$, and temperature remained at levels considered suitable for this species (BALDISSEROTTO; RADÜNZ NETO, 2004). The values of sperm concentration found in this study were similar to those described by Borges et al. $(2005)\left(6.6 \times 10^{10} \pm 3.6 \times 10^{10}\right.$ cells $\left.\mathrm{mL}^{-1}\right)$ and Sanches et al. (2011a) $\left(4.38 \times 10^{10}\right.$ cells $\left.\mathrm{mL}^{-1}\right)$. The production of oocytes was also within the normal range reported for this species (GOMES et al., 2000).

The time of sperm motility, of sperm diluted in uncontaminated water, was similar to the one determined by Hilbig et al. (2008) (23.9 \pm 2.7 seconds to $26.2 \pm 3.4$ seconds) and Sanches et al. (2011a) (22.19 \pm 1.03 seconds). Sperm survival rates were similar to those described by Tessaro et al. (2012) $(62.57 \pm 3.62$ to $93.52 \pm 0.85$ seconds). Sperm dilution in copper-contaminated water at concentrations above $45 \mathrm{mg} \mathrm{L}^{-1}$ had a negative effect on sperm motility, possibly due to the ability of heavy metals to bind to flagellum proteins affecting sperm motility (DIETRICH et al., 2010). Furthermore, at these concentrations, agglutination of sperm cells occurs, contributing to the inhibition of sperm motility. The loss of sperm motility may be associated with alterations in cell structure induced by pollutants, such as changes in the midpiece of the flagellum, an area that contains mitochondria and is involved in the production of energy. In the gold fish Carassius auratus, sperm exposure to $100 \mathrm{mg} \mathrm{L}^{-1}$ of mercury chloride reduced flagellum length, whereas exposure to $0.01 \mathrm{mg} \mathrm{L}^{-1}$ for 24 hours increased head length, width and area (VAN LOOK; KIME, 2003).

The heavy metals may also inhibit the activity of cytochrome-related proteins and enzymes 
responsible for redox functions (SORRENTINO et al., 2005). Copper, specifically, is able to interfere with osmoregulation (BIANCHINI et al., 2004) and oxygen consumption rate, through alterations in enzymes involved in metabolic functions, such as in the sodium pump (MCGEER et al., 2000; HANDY, 2003). Problems related to the effect of copper on $\mathrm{Na}^{+}$and $\mathrm{K}^{+}$ion transport, and on the ATPase enzyme activity were also observed in the common carp Cyprinus carpio (DE BOECK et al., 2003) and the Mozambique tilapia Oreochromis mossambicus (LI et al., 1998).

The negative effects of heavy metals on sperm motility have also been observed in other species. Despite the fact that Abascal et al. (2007) did not verify loss of sperm motility sea bass

(Dicentrarchus labrax) sperm after 20 seconds exposure to $100 \mathrm{ppm}$ of copper, water contaminated with $0.01 \mathrm{ppm}$ of mercury chloride significantly damaged sperm cells. Mode of action and toxicity of heavy metals and other pollutants are probably species specific.

Oocytes and embryos are also negatively affected by heavy metals and other pollutants, which may interfere with fertilization (WITECK et al., 2011) and embryonic development. Concentrations of $100 \mathrm{mg} \mathrm{L}^{-1}$ of mercury or cadmium completely inhibited sperm motility in the rainbow trout Oncorhynchus mykiss, and the exposure of its eggs to $10 \mathrm{mg} \mathrm{L}^{-1}$ of these metals for 4 hours reduced fertility rates (DIETRICH et al., 2010).

The results of the present study suggest that copper-contaminated water has toxic effects on gametes, embryos, and larvae of the silver catfish (Rhamdia quelen). Sperm quality was clearly affected by metal contamination, since sperm motility decreased linearly with an increase in metal concentration in water. In addition, fertilization and hatching rates were also affected when copper concentrations in water were above $0.0979 \mathrm{mg} \mathrm{Cu}^{+2}$ $\mathrm{L}^{-1}$ and $0.0331 \mathrm{mg} \mathrm{Cu}^{+2} \mathrm{~L}^{-1}$, respectively.
The damage caused by this pollutant is certainly cumulative and depends on several factors, such as concentration and time of exposure. This was confirmed by the observation that, under brief copper exposure, larval development was normal, whereas the amount of normal larvae decreased proportionally to copper increase in water used to hatch the embryos.

Hilbig et al. (2008) observed that eggs of $R$. quelen were also sensitive to lead-contaminated water at concentrations above $0.25 \mathrm{mg} \mathrm{PB} \mathrm{L}^{-1}$, whereas cadmium-contaminated water was seen to cause toxicity at levels above $40.42 \mathrm{mg} \mathrm{Cd} \mathrm{L}^{-1}$ (WITECK et al., 2011).

The negative effects of pollutants on fertilization and embryonic development may also be related to the effect of pollutants on the micropyle, preventing the entry of the sperm cell in the oocyte (KIME, 1995). The toxicity of heavy metals present in activating solutions also cause negative effects on the sperm (RURANGWA et al., 2004), particularly on the maintenance of cell integrity. Furthermore, exposure to heavy metals for long periods of time may damage the cell membranes of gametes and embryos (BROOKS et al., 1997), or affect physiological processes important for ontogenesis.

Despite evidence of the damage caused by exposure of $R$. quelen gametes, embryos, and larvae to copper-contaminated water, little is known about the mechanisms that control these processes. In general, low levels of copper-contaminated water affect the larvae. This may be due either to the direct effect of metals on gametes and embryos, or indirectly to the alteration or inhibition of important physiological processes for cellular energy production or ontogenesis.

\section{Conclusion}

Exposure of $R$. quelen gametes to coppercontaminated water can negatively influence the natural or artificial propagation of this species. 
Exposure to copper negatively affected sperm motility, oocyte fertilization, and egg hatching. In addition, it affected larval development by increasing larval abnormality.

\section{References}

ABASCAL, F. J.; COSSON, J.; FAUVEL, C. Characterization of sperm motility in sea bass: the effect of heavy metals and physicochemical variables on sperm motility. Journal of Fish Biology, Liverpool, v. 70, n. 2, p. 509-522, 2007.

BALDISSEROTTO, B.; RADÜNZ NETO, J. Criação de jundiá. Santa Maria: Universidade Federal de Santa Maria, 2004. 232 p.

BIANCHINI, A.; MARTINS, S. E. G.; BARCAROLLI, I. F. Mechanism of acute copper toxicity in euryhaline crustaceans: implications for the Biotic Ligand Model. International Congress Series, New York, v. 1275, p. 189-194, 2004.

BOMBARDELLI, R. A.; MÖRSCHBÄCHER, E. F.; CAMPAGNOLO, R.; SANCHES, E. A.; SYPERRECK, M. A. Insemination dose for artificial fertilization of grey jundia oocytes, Rhamdia quelen (Quoy \& Gaimard, 1824). Revista Brasileira de Zootecnia, Viçosa, MG, v. 35, n. 4, p. 1251-1257, 2006.

BORGES, A.; SIQUEIRA, D. R.; JURINITZ, D. F.; ZANINI, R.; AMARAL, F.; GRILLO, M. L.; OBERST, E. R.; WASSERMANN, G. F. Biochemical composition of seminal plasma and annual variations in semen characteristics of jundia Rhamdia quelen (Quoy \& Gaimard, Pimelodidae). Fish Physiology and Biochemistry, Amsterdam, v. 31, n. 1, p. 45-53, 2005.

BROOKS, S.; TYLER, C. R.; SUMPTER, J. P. Egg quality in fish: what makes a good egg? Reviews in Fish Biology and Fisheries, Dordrecht, v. 7, n. 4, p. 387-416, 1997.

DE BOECK, G.; DE WACHTER, B.; VLAEMINCK, A.; BLUST, R. Effect of cortisol treatment and/or sublethal copper exposure on copper uptake and heat shock protein levels in common carp, Cyprinus carpio. Environmental Toxicology and Chemistry, Amsterdam, v. 22, n. 5, p. 1122-1126, 2003.

DIETRICH, G. J.; CIERESZKO, A.; KOWALSKI, R. K.; RZEMIENIECKI, A.; BOGDAN, E.; DEMIANOWICZ, W.; DIETRICH, M.; KUJAWA, R.; GLOGOWSKI, J. Motility and fertilizing capacity of frozen/thawed sperm of Siberian sturgeon after a shorttime exposure of fresh semen to mercury and cadmium.
Journal of Applied Ichthyology, Berlin, v. 28, n. 6, p. 973-977, 2012.

DIETRICH, G. J.; DIETRICH, M.; KOWALSKI, R. K.; DOBOSZ, S.; KAROL, H.; DEMIANOWICZ, W.; GLOGOWSKI, J. Exposure of rainbow trout milt to mercury and cadmium alters sperm motility parameters and reproductive success. Aquatic Toxicology, Amsterdam, v. 97, n. 4, p. 277-284, 2010.

GOMES, L. C.; GOLOMBIESKI, J. I.; CHIPPARI GOMES, A. R. Biology of Ramdia quelen (Teleostei, Pimelodidae). Ciencia Rural, Santa Maria, v. 30, n. 1, p. 179-185, 2000.

HANDY, R. D. Chronic effects of copper exposure versus endocrine toxicity: two sides of the same toxicological process? Comparative Biochemistry and PhysiologyPart A, New York, v. 135, n. 1, p. 25-38, 2003.

HERNANDEZ CUADRADO, E. E.; SOLIS MURGAS, L. D.; OLIVEIRA FELIZARDO, V. de; RODRIGUES FERREIRA, M.; SOUZA ANDRADE, E. de. Extension of sperm motility leads to increased rates of fertilization and hatching in curimba, Prochilodus lineatus. Journal of Applied Ichthyology, Berlin, v. 30, n. 2, p. 329-333, 2014.

HILBIG, C. C.; BOMBARDELLI, R. A.; SANCHES, E. A.; OLIVEIRA, J. D. S.; BAGGIO, D. S.; SOUZA, B. E. Effect of lead on artificial fertilization and incubation of gray jundia (Rhamdia quelen) eggs. Acta Scientiarum Animal Science, Maringá, v. 30, n. 2, p. 217-224, 2008.

JEZIERSKA, B.; LUGOWSKA, K.; WITESKA, M.; SAMOWSKI, P. Malformations of newly hatched common carp larvae. Electronic Journal of Polish Agricultural Universities, Wroclaw, v. 3, n. 2, p. 1-10, 2000.

KIME, D. E. The effects of pollution on reproduction in fish. Journal of Fish Biology, Liverpool, v. 5, n. 1, p. 5296, 1995.

KOAKOSKI, G.; OLIVEIRA, T. A.; ROSA, J. G. S.; FAGUNDES, M.; KREUTZ, L. C.; BARCELLOS, L. J. G. Divergent time course of cortisol response to stress in fish of diferente ages. Physiology \& Behavior, Zurique, v. 106, n. 2, p. 129-132, 2012.

LAHNSTEINER, F.; MANSOUR, N.; BERGER, B. The effect of inorganic and organic pollutants on sperm motility of some freshwater teleosts. Journal of Fish Biology, Liverpool, v. 65, n. 5, p. 1283-1297, 2004.

LI, J.; QUABIUS, E. S.; WENDELAAR BONGA, S. E.; FLIK, G.; LOCK, R. A. C. Effects of water-borne copper on branchial chloride cells and $\mathrm{Na}+\mathrm{K}+$-ATPase activities in Mozambique tilapia (Oreochromis mossambicus). Aquatic Toxicology, Amsterdam, v. 43, n. 1, p. 1-11, 1998. 
MCGEER, J. C.; SZEBEDINSZKY, C.; MCDONALD, D. G.; WOOD, C. M. Effects of chronic sublethal exposure to waterborne $\mathrm{Cu}, \mathrm{Cd}$ or $\mathrm{Zn}$ in ,rainbow trout 1: Iono-regulatory disturbance and metabolic costs. Aquatic Toxicology, Amsterdam, v. 50, n. 3, p. 231-243, 2000.

MILESI, S. V.; BIASI, C.; RESTELLO, R. M.; HEPP, L. M. The effect of metals $(\mathrm{Cu}$ and $\mathrm{Zn})$ on the benthic macroinvertebrate community in streams in southern Brazil. Acta Scientiarum Biology Science, Maringá, v. 30, n. 3, p. 283-289, 2008.

ROMAGOSA, E.; SOUZA, B. E.; SANCHES, E. A.; BAGGIO, D. M.; BOMBARDELLI, R. A. Sperm motility of Prochilodus lineatus in relation to dilution rate and temperature ofthe activating medium. Journal of Applied Ichthyology, Berlin, v. 26, n. 5, p. 678-681, 2010.

RURANGWA, E.; KIME, D. E.; OLLEVIER, F.; NASH, J. P. The measurement of sperm motility and factors affecting sperm quality in cultured fish. Aquaculture, Amsterdam, v. 234, n. 1-4, p. 1-28, 2004.

RURANGWA, E.; ROELANTS, I.; HUYSKENS, G.; EBRAHIMI, M.; KIME, D. E.; OLLEVIER, F. The minimum effective spermatozoa: egg ratio for artificial insemination and the effects of mercury on sperm motility and fertilization ability in Clarias gariepinus. Journal of Fish Biology, Liverpool, v. 53, n. 2, p. 402-413, 1998.

SANCHES, E. A.; MARCOS, R. M.; BAGGIO, D. M.; TESSARO, L.; BALEN, R. E.; BOMBARDELLI, R. A. Sperm concentration estimate of fish semen using spermatocrit method. Revista Brasileira de Zootecnia, Viçosa, MG, v. 40, n. 6, p. 1163-1167, 2011 b.

SANCHES, E. A.; NEUMANN, G.; BAGGIO, D. M.; BOMBARDELLI, R. A.; PIANA, P. A.; ROMAGOSA, E. Time and temperature on the storage of oocytes from jundiá catfish, Rhamdia quelen. Aquaculture, Amsterdan, v. 319, n. 3-4, p. 453-458, 2011 a.
SARNOWSKI, P. The effects of metals on swimbladder inflation of common carp (Cyprinus carpio 1.) larvae. Electronic Journal of Polish Agricultural Universities, Wroclaw, v. 7, n. 1, p. 1-12, 2004.

SCOTT, G. R.; SLOMAN, K. A. The effects of environmental pollutants on complex fish behaviour: integrating behavioural and physiological indicators of toxicity. Aquatic Toxicology, Amsterdam, v. 68, n. 4, p. 369-392, 2004.

SORRENTINO, C.; ROY, N. K.; COURTENAY, S. C.; WIRGIN, I. Co-exposure to metals modulates CYP1A mRNA inducibility in Atlantic tomcod Microgadus tomcod from two populations. Aquatic Toxicology, Amsterdam, v. 75, n. 3, p. 238-252, 2005.

TESSARO, T.; TOLEDO, C. P. R.; NEUMANN, G.; KRAUSE, R. A.; MEURER, F.; NATALI, M. R. M.; BOMBARDELLI, R. A. Growth and reproductive characteristics of Rhamdia quelen males fed on different digestible energy levels in the reproductive phase. Aquaculture, Amsterdam, v. 326-329, p. 74-80, 2012.

VAN LOOK, K. J. W.; KIME, D. E. Automated sperm morphology analysis in fishes: the effect of mercury on goldfish sperm. Journal of Fish Biology, Liverpool, v. 63, n. 4, p. 1020-1033, 2003.

VIVEIROS, A. T. M.; ISAÚ, Z. A.; CANEPPELE, D.; LEAL, M. C. Sperm cryopreservation affects posthaw motility, but not embryogenesis or larval growth in the Brazilian fish Brycon insignis (Characiformes). Theriogenology, Stoneham, v. 78, n. 4, p. 803-810, 2012.

WITECK, L.; BOMBARDELLI, R. A.; SANCHES, E. A.; OLIVEIRA, J. D. S.; BAGGIO, D. M.; SOUZA, B. E. Sperm motility, oocyte fertilization and egg hatching on Jundiá catfish in cadmium contaminated water. Revista Brasileira de Zootecnia, Viçosa, MG, v. 40, n. 3, p. 477-481, 2011. 
